\title{
Effect of defatted soybean flour on physico-chemical, mineral and sensory quality attributes of Chapati
}

\author{
- Syed ZubaiR*, P.N. SATWAdHAR and D.R. MORE
}

Department of Food Trade and Business Management, College of Food Technology, Vasanthrao Naik Marathwada Krishi Vidyapeeth, PARBHANI.(M.S) INDIA (E-mail : zubair.foodtech@gmail.com)

*Author for Correspondence

Research chronicle : Received : 23.04.2017; Revised : 14.05.2017; Accepted : 27.05.2017

\section{SUMMARY :}

Present work have been undertaken to formulate and evaluate the qualities of defatted soybean flour based Chapati. The Chapati is made up of blending of wheat flour and different proportion of defatted soybean flour. Four treatments were used with sample code $\mathrm{T}_{0}, \mathrm{~T}_{1}, \mathrm{~T}_{2}$ and $\mathrm{T}_{3}$ i.e. $0,20,30$ and 40 per cent substitution of defatted soybean flour. The prepared Chapati was evaluated for its sensory acceptability using 9 point hedonic scale. It was found that treatment $T_{2}$ containing 30 per cent defatted soybean flour got the highest score as compared to other treatments. Hence, this proportion of flours was used for further study. Physical analysis of Chapati revealed that weight of sample $\mathrm{T}_{0}, \mathrm{~T}_{1}, \mathrm{~T}_{2}$ and $\mathrm{T}_{3}$ was observed 38.4, 40.6, 41.7 and $42.9 \mathrm{~g}$, respectively. Thicknesses of Chapaties were also increased from 2.3 to $2.8 \mathrm{~mm}$ with increasing levels of defatted soybean flour with decrease in diameter from 19 to $17.5 \mathrm{~cm}$. Ash contents of sample $\mathrm{T}_{0}, \mathrm{~T}_{1}, \mathrm{~T}_{2}$ and $\mathrm{T}_{3}$ were 1.38, 2.32, 2.72 and 3.14 per cent, respectively. The fat contents of sample $\mathrm{T}_{0}, \mathrm{~T}_{1}, \mathrm{~T}_{2}$ and $\mathrm{T}_{3}$ were 1.90, 2.66, 3.12 and 3.53 per cent, respectively. The protein contents of sample $\mathrm{T}_{0}, \mathrm{~T}_{1}, \mathrm{~T}_{2}$ and $\mathrm{T}_{3}$ were 10.06, 19.68, 23.62 and 27.56 per cent, respectively. The fibre contents of sample $\mathrm{T}_{0}, \mathrm{~T}_{1}, \mathrm{~T}_{2}$ and $\mathrm{T}_{3}$ were 1.50, 2.35, 2.60 and 2.85 per cent, respectively. The carbohydrate content of sample $\mathrm{T}_{0}, \mathrm{~T}_{1}, \mathrm{~T}_{2}$ and $\mathrm{T}_{3}$ were 56.94, $43.03,36.88$ and 30.76 per cent, respectively. The calcium, phosphorus, manganese, iron and zinc contents of control sample were $48.67,349.22,2.71,7.77$ and $2.23 \mathrm{mg} / 100 \mathrm{~g}$, respectively. The calcium, phosphorus, manganese, iron and zinc contents of sample $\left(\mathrm{T}_{2}\right)$ were 109.36, 443.20, 2.77, 15.6 and $1.99 \mathrm{mg} / 100 \mathrm{~g}$, respectively. It was concluded that the Chapati sample $\mathrm{T}_{2}$ containing 70 per cent whole wheat flour and 30 per cent defatted soybean flour was most desirable in terms of sensory and nutritional quality profile.

KEY WORDS :Defatted soybean flour, Wheat flour, Protein, Minerals

How to cite this paper : Zubair, Syed, Satwadhar, P.N. and More, D.R. (2017). Effect of defatted soybean flour on physico-chemical, mineral and sensory quality attributes of Chapati. Internat. J. Proc. \& Post Harvest Technol., 8 (1) : 44-49. DOI: 10.15740/HAS/IJPPHT/8.1/44-49. 